\title{
Evaluating the feasibility of oil palm agroforestry in Harapan Rainforest, Jambi, Indonesia
}

\author{
Tabah Arif Rahmani ${ }^{1}$, Dodik Ridho Nurrochmat ${ }^{2, *}$, Yulius Hero ${ }^{2}$, Mi Sun Park ${ }^{3}$, Rizaldi Boer ${ }^{4}$, Arif \\ Satria ${ }^{5}$ \\ 1 Forest Management Science Program of the Graduate School, IPB University Bogor, Indonesia; \\ tabah_ipb@apps.ipb.ac.id \\ 2 Department of Forest Management, Faculty of Forestry and Environment, IPB University Bogor, Indonesia; \\ yuliushe@apps.ipb.ac.id \\ 3 Graduate School of International Agricultural Technology, Institutes of Green-bio Science \& Technology, \\ Seoul National University, Republic of Korea; mpark@snu.ac.kr \\ 4 Centre for Climate Risk and Opportunity Management in Southeast Asia Pacific (CCROM-SEAP), IPB \\ University Bogor, Indonesia; ccrom_rizaldi@apps.ipb.ac.id \\ 5 Department of Communication and Community Empowerment Sciences, Faculty of Human Ecology, IPB \\ University Bogor, Indonesia; arifsatria@apps.ipb.ac.id \\ * Correspondence author: dnurrochmat@apps.ipb.ac.id; Tel.: +62-813-1484-5101
}

\begin{abstract}
About 2.5 million hectares of a total of 15 million hectares of oil palm plantation in Indonesia are planted in, or conflict with, the forest zone. Oil palm plantations face a conflict between socio-economic and ecological issues. This study was conducted in the Harapan Rainforest, Jambi to evaluate the potential of oil palm-based agroforestry to reconcile economic and ecological interests, by considering socio-economic and financial feasibility as well as biodiversity and land cover. The financial feasibility of oil palm agroforestry is compared to oil palm monoculture, employing a discounted cash flow approach using three indicators: net present value (NPV), benefit-cost ratio (BCR), and internal rate of return (IRR). Two ecological indicatorsbiodiversity and land cover-are evaluated in an experimental plot of oil palm agroforestry in Jambi. This study indicates that the NPV, BCR, and IRR of oil palm monoculture are IDR 62,644,836 (US\$ 4,476.84), 1.39, and $20.77 \%$, respectively, while the oil palm agroforestry planted in the experimental plot potentially generates much better values of financial indicators with NPV, BCR, and IRR being IDR 209,221,212 (US\$ $14,951.76), 1.79$, and $24.42 \%$, respectively. Besides evaluating financial feasibility, we also found that the reviewed current studies indicate that the oil palm agroforestry provides positive ecological impacts, such as increased forest land cover, invertebrate fauna, and bird diversity.
\end{abstract}

Keywords: financial feasibility; land use policy; oil palm agroforestry; sustainable forest management; Harapan Rainforest

\section{Introduction}

The increasing demand for palm oil globally has led to the rapid expansion of oil palm plantations in the Southeast Asia region (Sequiño \& Avenido, 2015). Transformation of complex natural rainforest into an economically purposed production system such as plantation of oil palm (Elaeis guineensis) is common, and oil palm is presumed to be a significant driver of biodiversity loss and social crisis in Southeast Asia (Gellert, 2015; Immerzeel et al., 2014; Koh \& Wilcove, 2008). In some cases, oil palms are planted in forest zones (Kehati, 2019) and are considered an important driver of forest fires and tenurial conflicts in several regions of Indonesia (Koh \& Wilcove, 2009; Lambin \& Meyfroidt, 2011).

Conflicts of interest between ecology and economy are found in many places in Indonesia (Adalina et al., 2014; Harbi et al., 2018; Nurrochmat et al., 2017; Nurrochmat et al., 2021). For instance, thousands of hectares in the Harapan Rainforest, Jambi, Sumatera - that are currently under land encroachment by the local communities and converted into oil palm plantations - have been designated by the Indonesian government for restoration of the lowland rainforest ecosystem. The forest is managed by PT Restorasi Ekosistem Indonesia (PT REKI), a company holding a license from the Ministry of Environment and Forestry to operate forest ecosystem restoration (IUPHHK$\mathrm{RE})$. The restoration of the forest ecosystem is not easily implemented because of the increasing 
demand for agricultural land from farmers owning very small tracts-less than a hectare per household (Nurrochmat, 2017). Conflict of interest on forestlands occurs because of the needs of people for more land to generate better income and improve their livelihood (Nurrochmat et al., 2020). The conflict between local communities and companies makes forest management and ecosystem restoration activities ineffective and inefficient (Harbi et al., 2018; Nurrochmat et al., 2017). Some conflicts could be resolved through a national climate financing mechanism, however, many of them cannot be effectively implemented in the fields (Sheriffdeen et al., 2020). Thus, some more evidence-based approaches should be introduced to improve the effectiveness of conflict resolution in the fields.

Several studies have advocated the integration of biodiversity conservation into the management of oil palm plantations to create more diversified oil-palm landscapes in mitigating the negative environmental consequences (Foster et al., 2011; Koh et al., 2009). However, the feasibility and possibility of intercropping other trees amongst oil palm plantations (oil palm-based agroforestry) are questioned due to competition for resources (Koh et al., 2009; Phalan et al., 2009) and the absence of enabling policies (see Erbaugh \& Nurrochmat, 2019). Some scientific articles discuss how the enrichment planting of trees affects biodiversity, ecosystems, and the socioeconomics of oil palm plantations (Gérard et al., 2017; Teuscher et al., 2016). Enrichment planting of trees in oil palm landscapes (known as oil palm agroforestry) can be integrated with conservation activities and oil palm production. Enrichment planting makes the oil palm landscape more accessible to native species to form clusters of tree islands within the plantation (Koh et al., 2009; Phalan et al., 2009). These tree islands in agricultural landscapes are a cost-effective measure to enhance biodiversity and ecosystem functions (Cole et al., 2010).

Recent studies reported that an oil palm agroforestry could provide higher economic and ecological benefits than the monoculture oil palm (Khasanah et al., 2020; Teuscher et al., 2016; Yuniati et al., 2018). A research consortium of IPB University and its partners-University of Göttingen (Germany), University of Jambi, and the University of Tadulako, named the Collaborative Research Center 990 (CRC-990)/ Ecological and Socioeconomic Functions of Tropical Lowland Rainforest Transformation Systems (EFForTS)-has initiated and established an oil palm agroforestry experimental plot in Jambi, Indonesia. The preliminary results of these experiments indicate the possibility of integrating oil palms and trees in the same landscape using an enrichment planting approach (Teuscher et al., 2016). Oil palm agroforestry positively impacts the environment (ecology), characterized by more diverse bird and insect species on the enrichment planting plot compared to monoculture oil palm plantations (Teuscher et al., 2016). The decline in oil palm yields is a controversial issue in long-term plantation management and sustainable palm oil certification (see Sahide et al., 2015a). However, in the short term, it is also noteworthy that in the experimental plot there is no decrease in the yields of oil palm during the first two-year period after enrichment planting of trees between oil palm stands (Gérard et al., 2017). This study aims to fill the knowledge gap by evaluating the financial feasibility and reviewing potential ecological benefits of oil palm agroforestry to provide evidence to reports of previous studies.

\section{Contextual Background}

About $90 \%$ of oil palm plantations in Indonesia are located on Sumatra and Kalimantan islands (Kehati, 2019; Kiswanto et al., 2008), producing 95\% of Indonesia's crude palm oil (MoA, 2019). In Jambi, oil palm plantations, mostly practicing monoculture, have rapidly expanded (Widayati et al., 2012). In 2019, the area of oil palm plantations owned by the community (smallholders), large-scale private companies, and the state totaled $682,175,362,662$, and 20,430 hectares, respectively in Jambi Province (BPS, 2020; MoA, 2019).

A large number of forests in Indonesia have been converted into oil palm plantations (Cooper et al., 2019; Sumarga \& Hein, 2016; Vijay et al., 2016; Sahide et al., 2015b), with this expansion causing a reduction in forest cover in Jambi (Figure 1) (Drescher et al., 2016). Moreover, the expansion of oil palms into the forest zone also has social impacts such as increased incidence of 
tenurial conflicts and income inequality in several regions (Koh \& Wilcove, 2009; Lambin \& Meyfroidt, 2011).

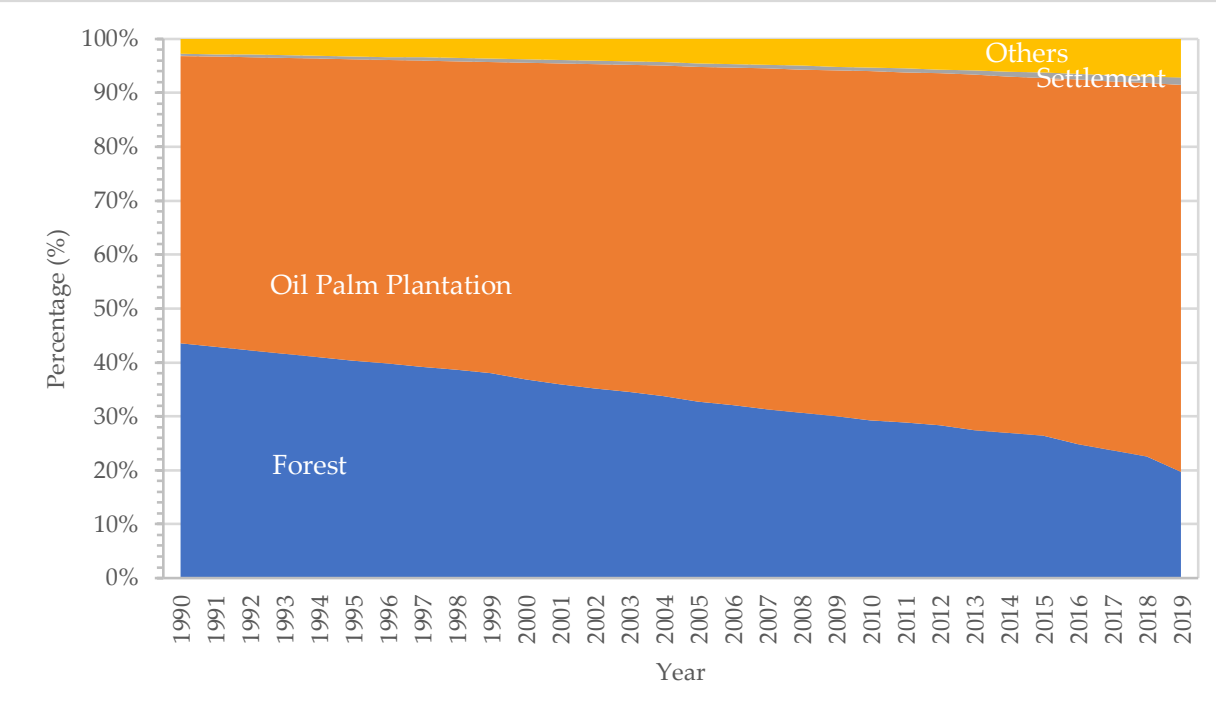

Figure 1. Percentage of land cover in Jambi Province from 1990-2019 (BPS-Jambi, 2020; MoA, 2019; MoEF, 2019).

In Indonesia, 3.4 million hectares of the total 16.8 million hectares under oil palm plantations are located in different forest zones and many of them occur as a result of conflicts over different government regulations (licensed plantations) and land encroachment (unlicensed plantations) (Kehati, 2019) (Figure 2).

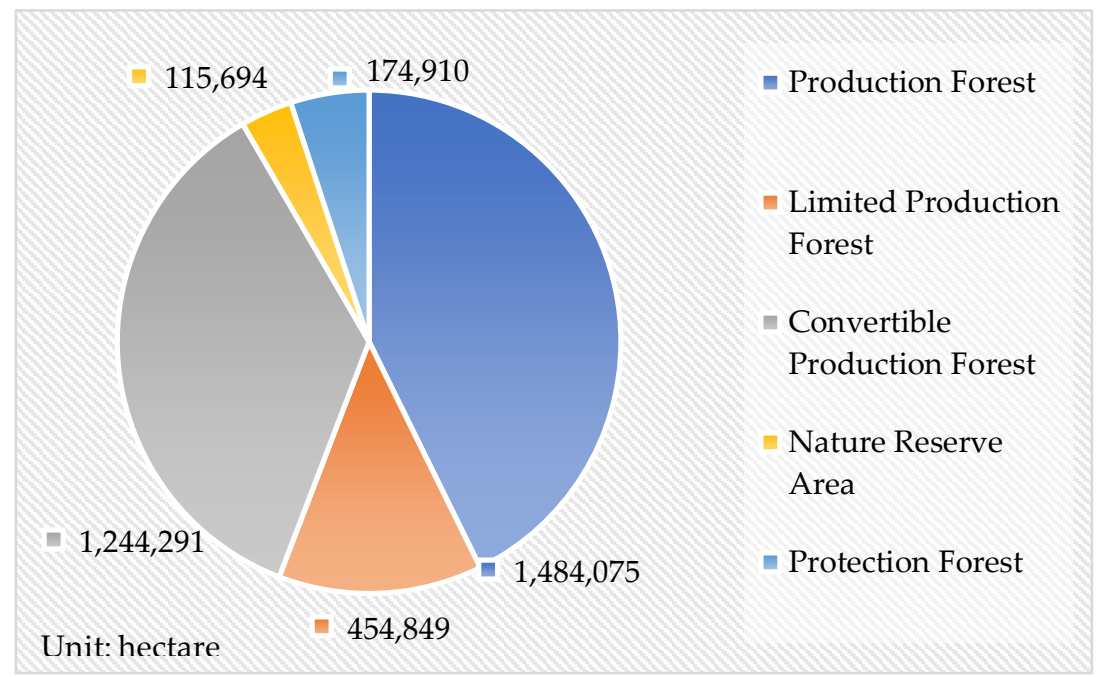

Figure 2. Oil palm plantation coverage in Indonesian forest zones (Kehati, 2019).

In Jambi, about 20,000 hectares of land in Harapan Rainforest, a restoration forest ecosystem managed by PT Restorasi Ekosistem Indonesia (PT REKI) has been encroached on by local communities and converted into oil palm plantations (MoEF, 2018). This situation causes a conflict in land utilization between local communities and companies and hinders the effectiveness and efficiency of the restoration of the forest ecosystem. To reconcile those interests, we consider promoting oil palm agroforestry as conflict resolution in the respective sites. Agroforestry is a spatial land-use system applying various agricultural crops and forestry plants, which are carried out simultaneously or in rotation over a certain period (Nair \& Garrity, 2012; Nair, 1993). It is one of the options of multi-business forestry schemes (MoEF, 2020). 
According to the Indonesian Minister of Forestry Regulation 14/2004, "a forest is defined as an area that extends more than 0.25 hectare, covering with trees that reach more than 5 meters in height at maturity and with a minimum of $30 \%$ canopy cover". As part of forest management, promoted oil palm agroforestry within the forest zone is required to meet this minimum threshold of the forest definition.

\section{Methods}

This study focuses on evaluating the financial feasibility of oil palm agroforestry and reviewing previous studies on the ecological impacts of oil palm agroforestry. The research framework presented in Figure 3.

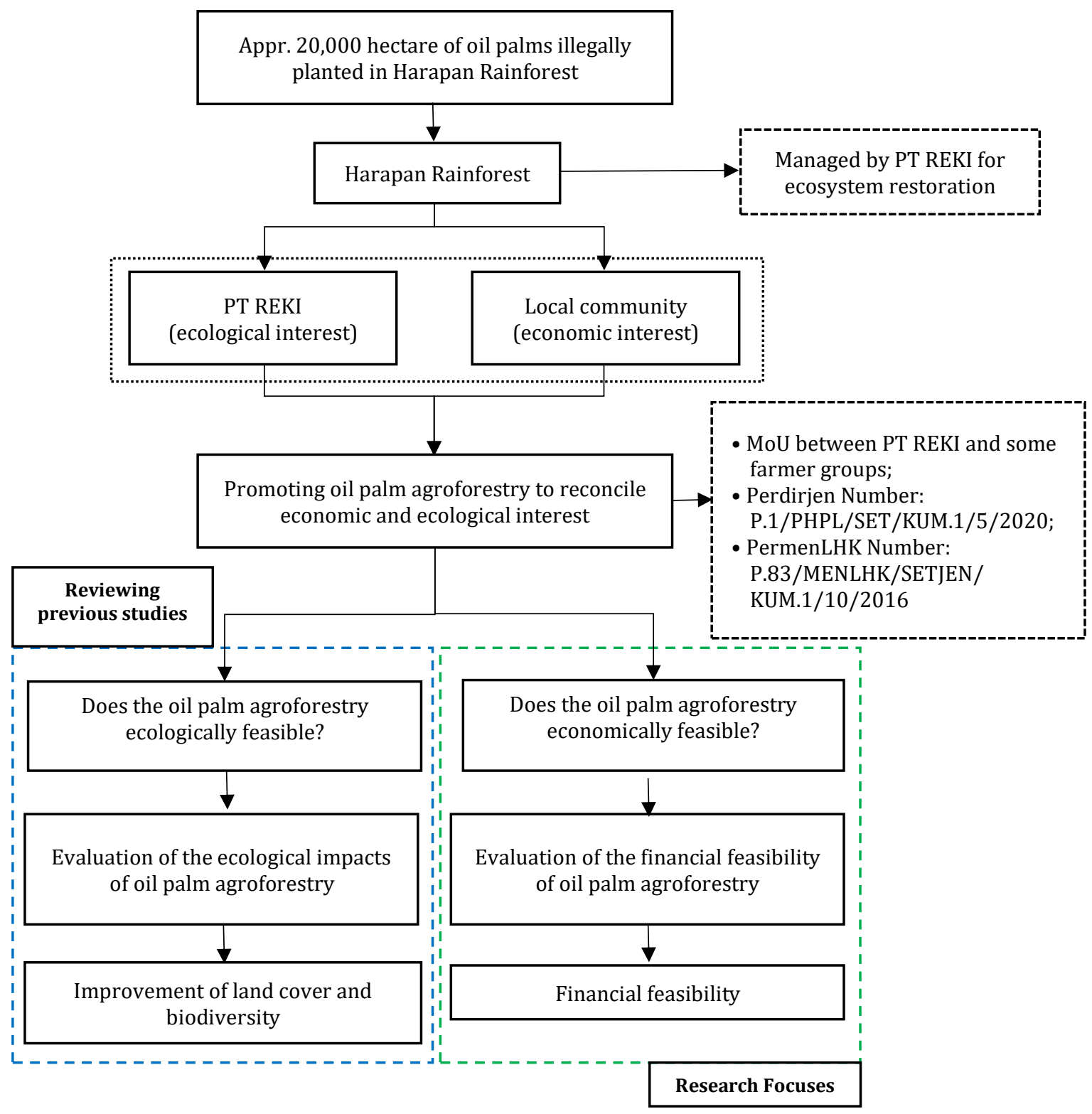

Figure 3. The research framework. 


\subsection{Study site}

This study's sites are located in the experimental plot B-11 of the CRC 990/ EFForTS in the oil palm-plantation area of PT HMS and the villages around the Harapan Rainforest managed by PT REKI in Batanghari District, Jambi Province (Figure 4).

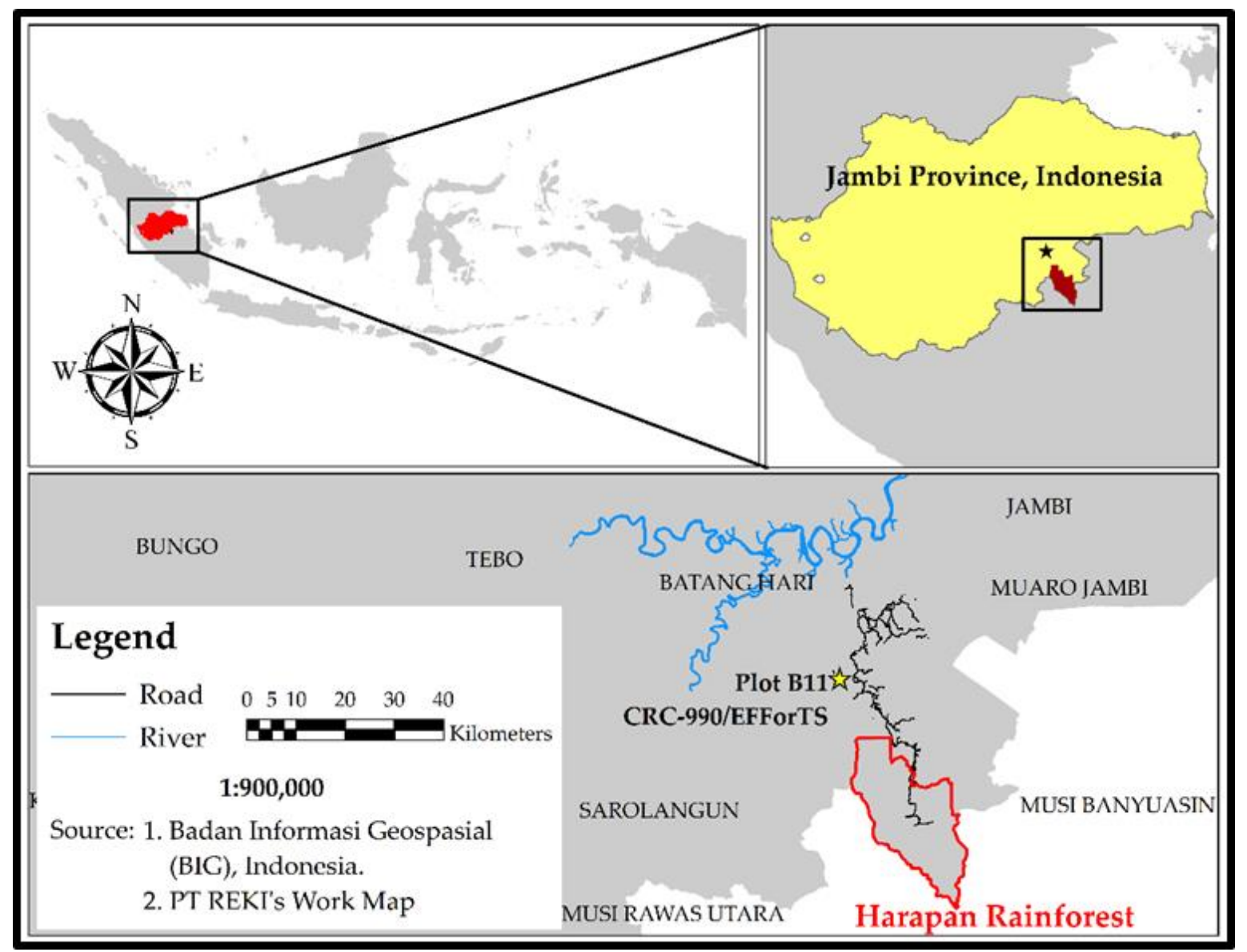

Figure 4. The research site.

Oil palm-based agroforestry has been practiced on the experimental plot of CRC 990/ EFForTS. This existing eight-year oil palm plantation is enriched by planting trees as intercrops (trees planted in between oil palm stands), such as jengkol or dog fruit (Archidendron pauciflorum), petai (Parkia speciosa), durian (Durio zibethinus), sungkai (Peronema canescens), meranti (Shorea leprosula), and jelutong (Dyera lowii). These plots were established in 2014, laid on the area dominated by a soil type of acrisol clay and surrounded by a lowland rainforest ecosystem (Allen et al., 2015). The number of oil palms per $40 \times 40$ sq. meter plot is around 13 trees, with spacing between the intercrops of $2 \times 2$ meters. There are approximately 81 oil palms and 2,500 trees (as intercrops) per hectare, although the number of trees used for intercropping in each plot varies by species. There are 56 experimental plots with different plot sizes: $40 \times 40$ sq. meter, $20 \times 20$ sq. meter, $10 \times 10$ sq. meter, and $5 \times 5 \mathrm{sq}$. meter (Figure 5) and differing degrees of biodiversity within the variety of intercrop trees (Figure 6). 


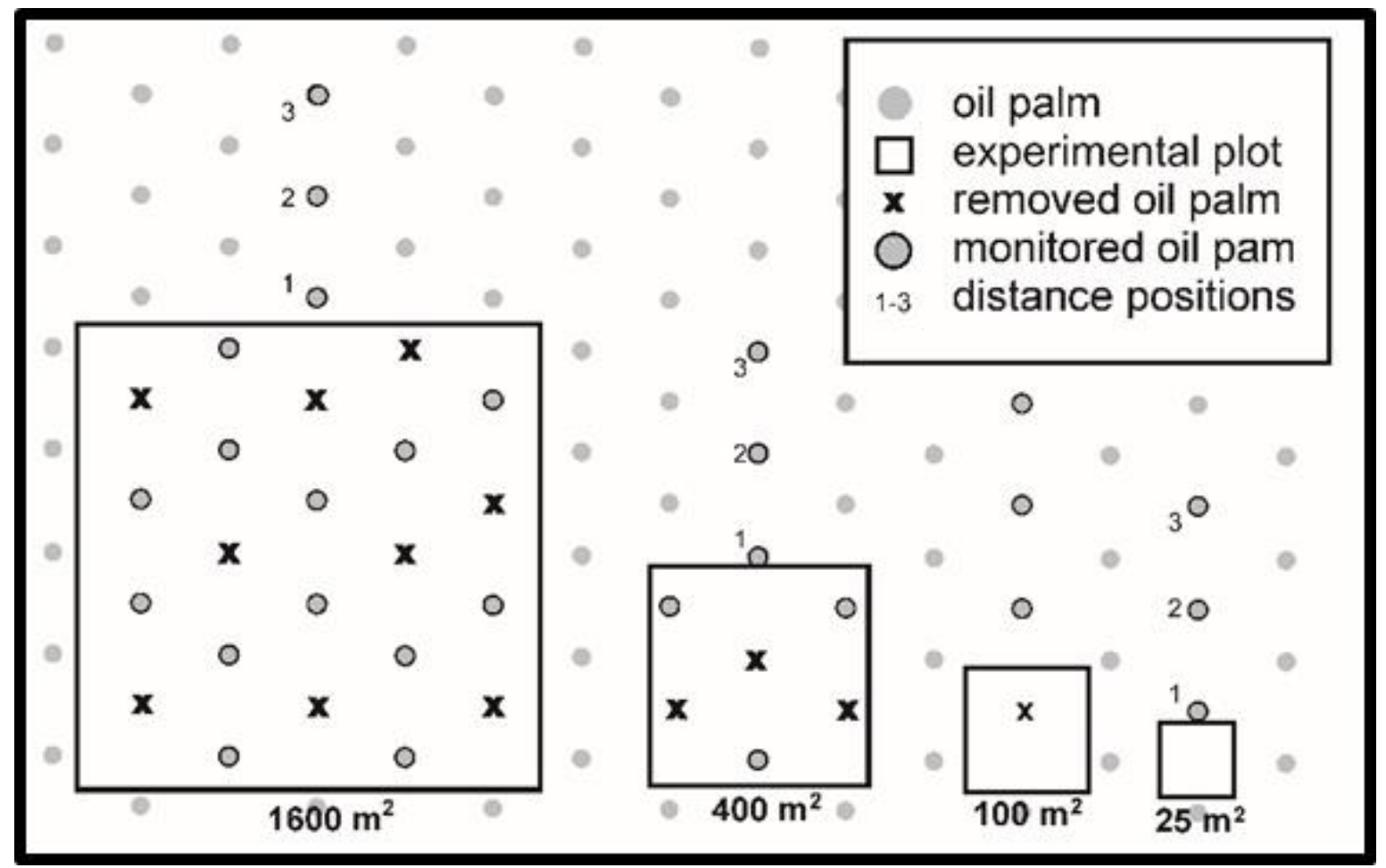

Figure 5. The experimental plots of oil palm agroforestry.

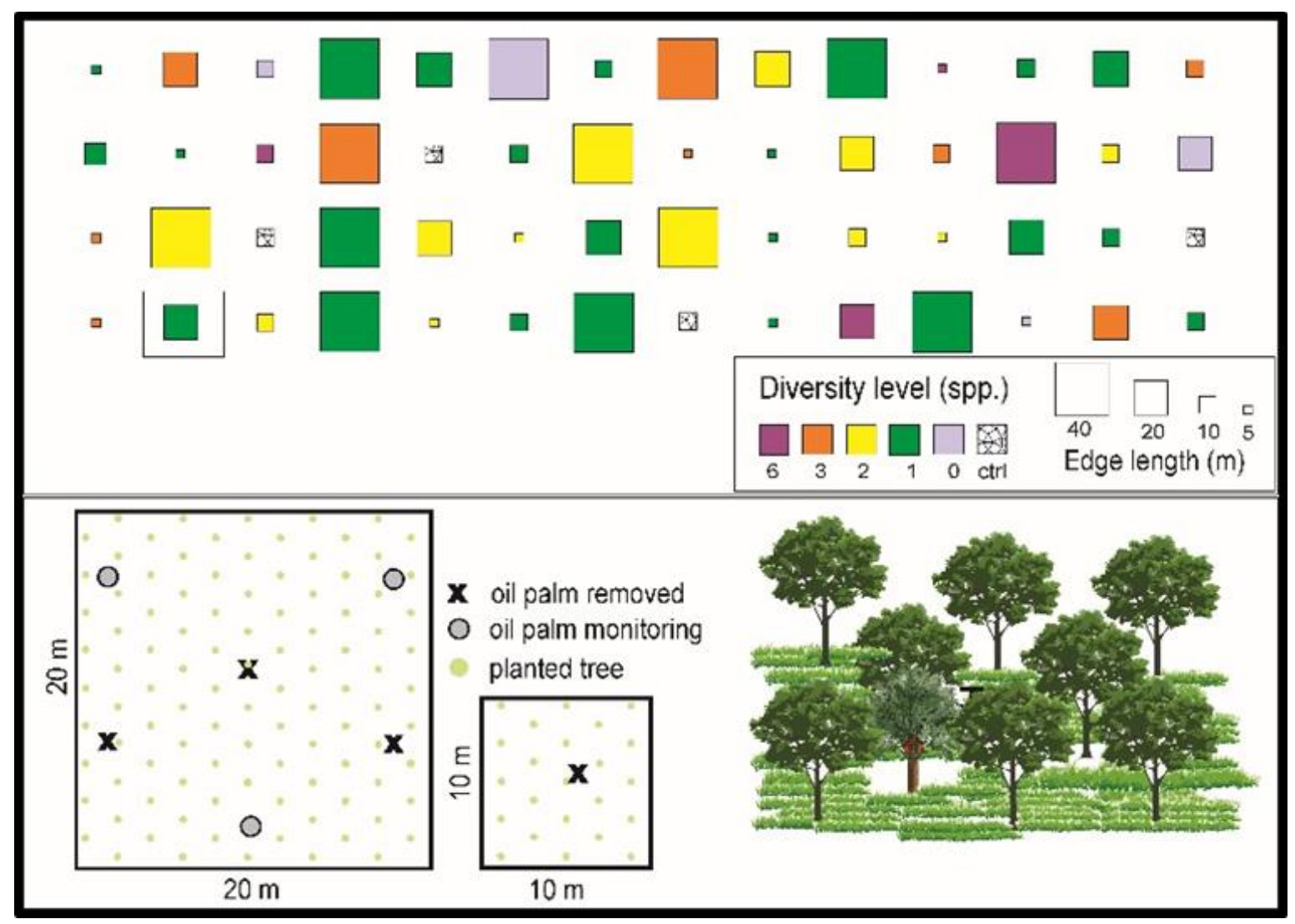

Figure 6. Degree of diversity in the experimental plots (Teuscher et al., 2016).

Harapan Rainforest is the only remaining tropical rain forest on the island of Sumatra, covering an area of 98,555 hectares. Currently, the Harapan Rainforest area is managed by PT Restorasi Ekosistem Indonesia (PT REKI) with an ecosystem restoration (RE) scheme since 2007. The main 
objective of PT REKI for ecosystem restoration is to restore and utilize the integrated natural production forest ecosystem in a sustainable manner, in terms of ecology, social, and economic perspectives (REKI, 2008).

\subsection{Data collection}

To conduct a financial feasibility analysis, this study collected data on the cost and revenue components of oil palm agroforestry and monoculture-oil palm plantations managed by the community, together with data from the experimental plots of CRC-990/EFForTS. We conducted interviews with 36 households around the Harapan Rainforest and surveyed 23 experimental plots of CRC-990/EFForTS. The socio-economic data on the people who owned oil palm plantations in the Harapan Rainforest were also employed. This study applied three techniques for collecting data, namely: (1) field observation, (2) key person interviews, and (3) gathering information and data from official documents belonging to agencies or companies, as well as scientific journals, books, research articles, proceedings, and digital media (internet sources). Field observations were conducted to obtain firsthand evidence of the existing conditions of the study sites in October 2019. Key person interviews were conducted with key respondents, including CRC-990/EFForTS staff and researchers, communities around the Harapan Rainforest, the management of PT HMS (oil palm company), and PT REKI (restoration ecosystem company) from December 2019 to January 2020. The key person interviews were conducted to explore data and to gather in-depth information for the research, such as cost components, commodity market prices, management issues, and (potential) obstacles in operating oil palm agroforestry. Data and information collected from the official documents, reports, and scientific articles were used to provide more evidence and strengthen the analysis.

Key persons selected as interview respondents included field managers and staff responsible for the management of the experimental agroforestry plot, eight people who owned oil palm plantations surrounding the experimental plot, and 36 people who planted oil palms inside the Harapan Rainforest-30 farmers (divided into five groups) had a Memorandum of Understanding (MoU) with PT REKI, while the balance of six farmers had not yet signed any MoU. Other interviews were conducted with key persons in PT REKI, including the operational director, the deputy manager for community partnership, and some field staffs related to the study.

\subsection{Data analysis}

This study conducted a discounted financial analysis to evaluate the feasibility of oil palm agroforestry and monoculture-oil palm plantations. The potential income generated from different combinations of oil palm agroforestry patterns were evaluated and compared with the needs of people and their existing income from monoculture-oil palm plantations. All costs and revenue components for a management period of 25 years were entered into a cash flow sheet. All benefits and costs were annually discounted-commonly referred to as discounted cash flow (Gittinger et al., 1993; Kadariah et al., 1999; Sutojo, 2000). The financial analysis indicators included net present value (NPV), benefit-cost ratio (BCR), and internal rate of return (IRR) (Kadariah et al., 1999; Sutojo, 2000). Each of those indicators was used to determine the feasibility of the project, estimate the future benefits of the project, and choose a more profitable project.

\subsubsection{Net Present Value (NPV)}

NPV is the difference between the present value of revenue and the present value of costs, or discounted future cash flows, yielding a current value. The project is financially feasible if NPV $>0$ (Kadariah et al., 1999; Sutojo, 2000). The equation for calculating NPV is:

$$
N P V=\sum_{t=0}^{n} \frac{B t-C t}{(1+i)^{t}}
$$

where:

NPV is the net present value (IDR);

$B t$ is gross revenue in $t$-year (IDR/year); 
$C t$ is gross cost in year $t$ (IDR/year);

$i$ is the interest rate, used as a discount factor (\%);

$t$ is the duration of the project period (in years) from year 0 to year $n$.

\subsubsection{Internal Rate of Return (IRR)}

IRR is the rate of return on capital in the evaluated project, at discount rate $i$, which makes the NPV equal to zero (NPV $=0$ ) -the value of $i$ where NPV $=0$. The project is financially feasible if the IRR > $i$ (Kadariah et al., 1999; Sutojo, 2000). The equation for calculating IRR is:

where:

$$
I R R=i_{1}+\frac{N P V_{1}}{N P V_{1}-N P V_{2}} \times\left(i_{1}-i_{2}\right)
$$

IRR is the internal rate of return;

$i_{1}$ is the interest rate that produces a positive NPV;

$i_{2}$ is the interest rate that produces a negative NPV;

$N P V_{1}$ is the nominal value of a positive NPV;

$N P V_{2}$ is the nominal value of negative NPV.

\subsubsection{Benefit-Cost Ratio (BCR)}

$B C R$ is a comparison between the value of benefits against the costs seen in the present value (PV) condition. A project is financially feasible if the BCR>1 (Kadariah et al., 1999; Sutojo, 2000). The equation for calculating BCR is as follows:

where:

$$
B C R=\frac{\sum_{t=1}^{n} \frac{B t}{(1+i)^{t}}}{\sum_{t=1}^{n} \frac{C t}{(1+i)^{t}}}
$$

$\mathrm{BCR}$ is the benefit-cost ratio;

$B t$ is benefit/revenue in year $t$;

$C t$ is the cost in year $t$;

$i$ is the interest rate which is used as a discount factor (\%);

$t$ is the duration of the project period (in years) from year 0 to year $n$.

After calculating the results of the financial analysis, the next step is to compare the financial indicators of the different land management patterns. In addition to NPV $>0, B C R>1$, and IRR $>i$, the proposed scheme of oil palm agroforestry is feasible if the net benefit derived from the scheme is higher than the existing financial benefit received by people farming a monoculture-oil palm plantation of equivalent land size.

\section{Results and Discussions}

\subsection{Harapan rainforest community socio-economic overview}

The communities that live in and around the Harapan Rainforest zone consist of three largeethnic groups: Migrant, Batin Sembilan, and Malay. A large group is further divided into small groups. A small group of Malay, Migrants, and the Batin Sembilan formed a farmer group (Kelompok Tani/KT) (Table 1). The farmer groups indicated in bold-italics were selected as respondents.

Table 1. Harapan Rainforest Farmer Groups.

\begin{tabular}{cllll}
\hline No & $\begin{array}{l}\text { Community } \\
\text { Group }\end{array}$ & Province & Location & Farmer Group \\
\hline 1 & & & Sako Suban \\
2 & Malay Groups & South Sumatra & Kapas Basin & $\begin{array}{l}\text { Rompok Baginde } \\
\text { Rompok Aur }\end{array}$ \\
3 & & & Rompok Landai \\
\hline
\end{tabular}




\begin{tabular}{|c|c|c|c|c|}
\hline No & $\begin{array}{l}\text { Community } \\
\text { Group }\end{array}$ & Province & Location & Farmer Group \\
\hline 5 & & & & Rompok Kapas Tengah \\
\hline 6 & & & & Rompok Bato \\
\hline 7 & \multirow{11}{*}{$\begin{array}{l}\text { Batin Sembilan } \\
\text { Groups }\end{array}$} & \multirow{8}{*}{ Jambi } & Simpang Macan Luar & Simpang Macan Luar Group \\
\hline 8 & & & & Tanding Group \\
\hline 9 & & & Bungin & Gelinding Group \\
\hline 10 & & & & KT Lamban Jernang \\
\hline 11 & & & Simpang Macan Dalam & Ruslan Group \\
\hline 12 & & & Simpang Macan Dalam & Herman Group \\
\hline 13 & & & $\mathrm{Km} .45$ & Khotib Group \\
\hline 14 & & & Sei Jerat & Jupri Group \\
\hline 15 & & \multirow{3}{*}{ South Sumatra } & Kapas Basin & Mat Liar Group \\
\hline 16 & & & Meranti Basin & Mat Kecik Group \\
\hline 17 & & & Hulu Badak & Burhan Group \\
\hline 18 & \multirow{11}{*}{$\begin{array}{l}\text { Migrant } \\
\text { Groups }\end{array}$} & \multirow{10}{*}{ Jambi } & \multirow{3}{*}{ Kunangan Jaya I } & KT Bungin Mandiri \\
\hline 19 & & & & KT Berkah Jaya \\
\hline 20 & & & & KT Mekar Jaya Indah \\
\hline 21 & & & \multirow{2}{*}{ Kunangan Jaya II } & KT Hijau Alam Lestari \\
\hline 22 & & & & KT Tani Jaya/Eko group \\
\hline 23 & & & Alam Sakti & Alam Sakti Group \\
\hline 24 & & & Tanjung Mandiri & Tanjung Mandiri Group \\
\hline 25 & & & Sei Jerat & SPI Group \\
\hline 26 & & & Hulu Badak & Bali Group \\
\hline 27 & & & Pangkalan Ranjau & Jupri Migrant Group \\
\hline 28 & & South Sumatra & Kapas Basin & Trans Bali-Lampung Group \\
\hline
\end{tabular}

Batin Sembilan is a traditional community native to Jambi and South Sumatra provinces (Syuroh, 2011). Eleven farmer groups are encroaching on the Harapan Rainforest, eight of them located in Jambi and the balance in South Sumatra. We interviewed four groups of the Batin Sembilan (Simpang Macan Luar, Tanding, Gelinding, and KT Lamban Jernang), and five groups of the migrant community (KT Bungin Mandiri, KT Berkah Jaya, KT Mekar Jaya Indah, KT Hijau Alam Lestari, and KT Tani Jaya/Eko).

The traditional people of Batin Sembilan had previously utilized timber, hunted animals, and collected non-timber forest products (NTPFs), but are currently only allowed to collect NTPFs. Many kinds of NTFPs are utilized by the Batin Sembilan people including sialang honey, fruits ( $D$. zibethinus, rambutan, and others), resin stones, and many others. Recognizing the success of their neighbors who planted oil palms in the Harapan Rainforest, the Batin Sembilan also planted oil palms in the forestlands. Some Batin Sembilan groups currently cultivate rubber plantations with the assistance of PT REKI, instead of extending their oil palms.

Malay people, also known as the Sako Suban, mostly live in Sako Suban Village. They depend extensively on rivers and forests. The Sako Suban use the river for transportation and make their livelihood through fishing and collecting shrimp. They also collect timber and NTFP's such as honey, fruits, game animals, and medicinal plants among others. Some people occasionally hunt illegally. Like other indigenous people in Sumatra, the Sako Suban has a historical background of shifting cultivation. However, over the last decade shifting agriculture has been prohibited, particularly after the involvement of PT REKI in the Harapan Rainforest (REKI, 2009).

Unlike the Batin Sembilan and the Sako Suban, migrants often use forestland for farming. Migrants are those who are not included in the Batin Sembilan or Malay (Sako Suban) ethnicities. Javanese and Bataknese are the dominant ethnicities. The migrants have higher levels of education, knowledge, and skills in modern farming and plantation cultivation compared to the Batin Sembilan. 
Migrants often demonstrate strong capabilities in managing land and marketing their products. Some migrant groups who have encroached on forestlands have converted them into oil palm plantations. Table 2 shows the characteristics of the 36 respondents gathered from interviews related to land uses in the Harapan Rainforest.

Table 2. Socio-economic characteristics of respondents in Harapan Rainforest.

\begin{tabular}{ll}
\hline Respondents' Characteristics & Total (percentage) \\
\hline Age & \\
20 to 35 years old & 6 people $(17 \%)$ \\
36 to 45 years old & 16 people $(44 \%)$ \\
45 to 60 years old & 13 people $(36 \%)$ \\
$>60$ years old & 1 people $(3 \%)$ \\
\hline Tribe & \\
Javanese & 25 people $(69 \%)$ \\
Batin Sembilan & 6 people $(17 \%)$ \\
Bataknese & 5 people $(14 \%)$ \\
\hline Gender & \\
Male & 35 people $(97 \%)$ \\
Female & 1 people $(3 \%)$ \\
\hline Main Job & \\
Resin collector & 4 people $(11 \%)$ \\
Farmer (oil palm) & 29 people $(80 \%)$ \\
Broker (oil palm fresh fruit bunches) & 2 people $(6 \%)$ \\
Employees of PT REKI & 1 people $(3 \%)$ \\
\hline Total Monthly Revenue & \\
<IDR 1,000,000 (US\$ 71.46) & 0 people $(0 \%)$ \\
IDR 1,000,000-3,000,000 (US\$ 71.46-214.39) & 5 people (14\%) \\
IDR 3,000,000- 5,000,000 ((US\$ 214.39-357.32) & 16 people $(44 \%)$ \\
$>$ IDR 5,000,000 (US\$ 357.32) & 15 people (42\%) \\
Average monthly expenditure & IDR 4,100,000 (US\$ 293)/household \\
\hline Average size of farmlands & \\
Oil palm plantation & 4.85 hectares/household \\
Rubber plantation & 1.75 hectares/household \\
\hline
\end{tabular}

\subsection{Monoculture-oil palm plantation financial feasibility}

A financial feasibility analysis was conducted targeting a monoculture-oil palm plantation. The data on costs and revenues were obtained from the interviews with key persons in PT HMS and PT REKI as well as communities who live in and around the Harapan Rainforest. Oil palm is commonly planted at a distance of $9 \times 9$ meters in an equilateral triangle pattern-about 135 oil palm trees per hectare. The oil palm usually starts to be fruited after the third year, although these first fruits are still too young and cannot be sold to the palm oil mills, only becoming salable from four years old.

This study applied some definitions and assumptions for the financial analysis of monocultureoil palm plantation:

- The financial analysis is based on a one-hectare area;

- The productive age of oil palms is 25 years (an investment period of 25 years);

- Land investment and land tax costs are excluded;

- The cost components of land clearing, seedlings, planting, maintenance, and harvesting are assumed as employee expenses or costs incurred by oil palm plantation companies;

- The yield per hectare is 135 oil palms;

- All oil palm trees are deemed to be growing well and fruited normally throughout the period;

- Application of fertilizers and herbicides follows oil palm plantation companies in the research 
site;

- The price of oil palm fresh fruit bunches (FFBs) is IDR 1,500 (US\$ 0.11)/kg;

- The FFBs are harvested once a month;

- The interest rate, applied as the discount factor, is $9.9 \%$;

- The oil palm productivity curve follows prior research (Sufriadi, 2015).

From the results in Table 3, this study indicates that the monoculture-oil palm plantation is financially feasible because $N P V>0, B C R>1$, and IRR $>i$. The highest income from the plantationindicating the peak of oil palm productivity-is reached for palms between the ages of 9 to 15 years. The average potential annual income is IDR $28,452,833$ (US\$2,033.35)/hectare (IDR 2,371,069 or US\$ $169.45 /$ hectare monthly). Moreover, the average cost is IDR $16,610,350 /$ hectare/year (IDR $1,384,195 /$ hectare/month). Consequently, the potential net benefit of the monoculture oil palm plantation is only IDR 986,874 (US\$ 70.53)/hectare/month.

Table 3. NPV, BCR, and IRR of the monoculture-oil palm plantation.

\begin{tabular}{ll}
\hline Indicators & Result \\
\hline NPV & IDR 62,644,836 (US\$ 4,476.84) \\
BCR & 1.39 \\
IRR & $20.77 \%$ \\
\hline
\end{tabular}

\subsection{Oil palm agroforestry financial feasibility}

A financial feasibility analysis was also conducted in the experimental oil palm agroforestry plot. The intercrop trees are planted when the oil palm is eight years old. Initially, the oil palm is planted with a spacing of $9 \times 9$ meters in an equilateral triangle pattern. When enrichment planting was applied, about nine oil palm trees were cut down on a 40x40 sq. meter plot, reducing it to only 13 oil palm trees (Figure 3).

According to field observations, the intercropped trees in the experimental agroforestry plot were generally able to grow well. Oil palms in the plot were also fruited regularly. Jengkol, sungkai, and petai grew well, indicated by their large stem diameter. Jengkol had already begun to bear fruit in the fifth year. Meranti and jelutong were generally growing slightly smaller than jengkol. Even though meranti is classified as a semi-intolerant plant (Setiawan et al., 2015), their growth height was almost equal to the jengkol. The jelutong also had a height and diameter of approximately the same as meranti. Durian grew slower than other plants. During the long dry season (at the time of field research), the Durian shed most of its leaves and appeared to be depressed, indicated by a smaller diameter and height compared to the other plants.

The definitions and assumptions applied for the financial analysis of oil palm agroforestry followed those of the monoculture analysis with the following exceptions:

- The initial number of oil palms is 135 trees per hectare, and after the thinning and enrichment planting (in the eighth year) the remaining oil palms are 81 trees per hectare;

- Planting intercrop trees are conducted when the oil palm is eight years old;

- The total number of intercrops is 2,500 trees per hectare, with the number of each species is around $416-417$ trees per hectare;

- All intercrop plants and oil palms can grow and bear fruit normally until the end of the period;

- Fertilization is only applied on oil palm;

- The price of Petai follows the price in Batanghari Regency market of IDR 1,000 (US\$0.071)/piece, and petai starts to bear fruit at the age of seven years, will decrease productivity at age;

- The price of jengkol follows the price in the Batanghari Regency market of IDR 5,000 (US\$ $0.36) / \mathrm{kg}$ (unpeeled), and jengkol starts to bear fruit at the age of five years;

- The price of durian follows the price in the Batanghari Regency market of IDR 20,000 (US\$ 1.43)/piece, and durian starts to bear fruit at the age of ten years;

- The price of sungkai log follows the price issued by the Indonesian Forestry Concession 
Association (APHI) of IDR 1,800,000 (US\$128.64)/ $/ \mathrm{m}^{3} \mathrm{log}$, harvested the end of the investment period;

- The price of meranti log follows the price issued by the Indonesian Forestry Concession Association (APHI) of IDR 1,000,000 (US\$71.46) $/ \mathrm{m}^{3} \mathrm{log}$, harvested at the end of the investment period;

- The price of jelutong sap follows the selling price in the Batanghari Regency previous market of IDR 4,000 (US\$ 0.29)/kg;

- The productivity of each enrichment plant follows the literature in Table 4;

- Harvest of petai, jengkol, and durian is conducted once a year.

Table 4. Crop productivity.

\begin{tabular}{|c|c|c|c|c|c|c|}
\hline Crop & $\begin{array}{l}\text { Time to } \\
\text { Harvest } \\
\text { (years) }\end{array}$ & $\begin{array}{l}\text { Productive } \\
\text { age (years) }\end{array}$ & $\begin{array}{c}\text { Productivity per } \\
\text { tree }\end{array}$ & $\begin{array}{l}\text { Est. age of } \\
\text { declining } \\
\text { productivity }\end{array}$ & $\begin{array}{l}\text { Est. annual } \\
\text { decline in } \\
\text { production }\end{array}$ & Source \\
\hline Petai & 7 & 25 & 60 pcs /year & 15 & $2 \%$ & $\begin{array}{l}\text { (Sunanto, 1999; } \\
\text { Susilo, 2012) }\end{array}$ \\
\hline Jengkol & 5 & 20 & 20 kg/year & 12 & $5 \%$ & (Pitojo, 1992) \\
\hline Durian & 10 & 25 & 25 pcs /year & 18 & $3 \%$ & $\begin{array}{l}\text { (Sobir, 2009; } \\
\text { Sobir \& } \\
\text { Napitupulu, } \\
\text { 2010) }\end{array}$ \\
\hline Sungkai & 30 & 30 & $0.47 \mathrm{~m}^{3} /$ cycle & - & - & $\begin{array}{c}\text { (Wahyudi, } \\
\text { 2016; Wahyudi, } \\
\text { Damiri, } \\
\text { Christopheros, } \\
\text { \& Pahawang, } \\
\text { 2018) }\end{array}$ \\
\hline Meranti & 35 & 35 & $0.47 \mathrm{~m}^{3} /$ cycle & - & - & $\begin{array}{c}\text { (Hadi \& } \\
\text { Napitupulu, } \\
\text { 2011) }\end{array}$ \\
\hline Jelutong & 10 & 30 & $18.31 \mathrm{~kg} /$ year & 15 & $5 \%$ & $\begin{array}{c}\text { (Tata et al., } \\
\text { 2015) }\end{array}$ \\
\hline Oil Palm & 4 & 25 & 180 kg/year & 15 & $4 \%$ & $\begin{array}{c}\text { (Lubis \& } \\
\text { Widanarko, } \\
\text { 2012; Sufriadi, } \\
\text { 2015; Wijayanti } \\
\text { \& Mudakir, } \\
\text { 2013) }\end{array}$ \\
\hline
\end{tabular}

As per Table 5, this study concludes that oil palm agroforestry is financially feasible because $N P V>0, B C R>1$, and IRR $>i$. Oil palm agroforestry is estimated to produce an average potential annual income of IDR 101,508,766 (US\$ 7254.21)/hectare, or an average potential monthly income of IDR $8,459,064$ (US\$ 604.62)/hectare. The costs incurred for implementing this scheme are quite high with an average cost, IDR 42,404,307 (US\$ 3030.38)/hectare/year, or IDR 3,533,692 (US\$ $252.53) /$ hectare/month. Therefore, the potential net profit of the oil palm agroforestry is an estimated IDR 4,925,372 (US\$ 351.99)/hectare/month.

Table 5. NPV, BCR, and IRR of the oil palm agroforestry.

\begin{tabular}{ll}
\hline Indicators & Result \\
\hline NPV & IDR 209,221,212 (US\$ 14951.76) \\
BCR & 1.79 \\
IRR & $24.42 \%$ \\
\hline
\end{tabular}

Oil palm agroforestry is more profitable compared to monoculture-oil palm cultivation. This follows a previous study that reports the application of oil palm agroforestry as much more 
profitable than monoculture-oil palm cultivation (Yuniati et al., 2018) arising from diversification of products through land management, with a potential increase in the associated income (Muryunika, 2015; Phimmavong et al., 2019; Wanderi et al., 2019). The selection of agroforestry intercrops is an important factor in increasing the probability of successful implementation (Yuniati, 2018). Moreover, site suitability and the price and market for the plant yields are critical.

\subsection{Promoting optimal planting in oil palm agroforestry}

Based on field observations, there are several findings regarding the spacing of enrichment plants. Narrow spacing causes difficulties in harvesting practices of oil palm fruits and increases harvesting time. Moreover, many intercrop plants were damaged or died due to the falling of oil palm trunks, branches, and fruit while harvesting, thinning, or replanting. Therefore, widening planting space is important to enhance the viability of the intercrops and to facilitate greater safety in oil palm agroforestry management (see Yovi \& Nurrochmat, 2018).

Based on insights arising from the experimental plot, oil palm agroforestry stakeholders should consider the optimal planting distance of each plant used for intercropping (Table 6). Securing planting space effectively simplifies the process of maintenance and harvesting. An optimal planting distance increases the chance of intercrops thriving. Thus, we propose six combinations of intercrop spacing in an oil palm agroforestry pattern (Table 7).

Table 6. Optimal spacing for intercrop plants.

\begin{tabular}{|c|c|c|c|c|}
\hline Plant & $\begin{array}{c}\text { Optimal Planting } \\
\text { Distance (sq. meter) }\end{array}$ & $\begin{array}{c}\text { Age can be } \\
\text { harvested (year) }\end{array}$ & $\begin{array}{l}\text { Productive age } \\
\text { (year) }\end{array}$ & Source \\
\hline Petai & $3 \times 3$ to $5 \times 5$ & 7 & 25 & (Sunanto, 1999; Susilo, 2012) \\
\hline Jengkol & $3 \times 3$ to $5 \times 5$ & 5 & 20 & (Pitojo, 1992) \\
\hline Durian & $5 \times 5$ to $8 \times 8$ & 10 & 25 & $\begin{array}{c}\text { (Sobir, 2009; Sobir \& } \\
\text { Napitupulu, 2010) }\end{array}$ \\
\hline Sungkai & $3 \times 3$ & 30 & 30 & $\begin{array}{c}\text { (Wahyudi, 2016; Wahyudi et } \\
\text { al., 2018) }\end{array}$ \\
\hline Meranti & $3 \times 3$ & 35 & 35 & (Hadi \& Napitupulu, 2011) \\
\hline Jelutong & $3 \times 4$ & 10 & 30 & $\begin{array}{c}\text { (Tata et al., 2015) } \\
\text { (Lubis \& Widanarko, 2012; }\end{array}$ \\
\hline Oil palm & $8 \times 9$ & 4 & 25 & $\begin{array}{c}\text { Sufriadi, 2015; Wijayanti \& } \\
\text { Mudakir, 2013) }\end{array}$ \\
\hline
\end{tabular}

Table 7. Oil palm agroforestry intercropping combinations and plant spacing.

\begin{tabular}{|c|c|c|c|c|c|c|c|c|}
\hline \multirow[b]{2}{*}{ Pattern } & \multirow{2}{*}{$\begin{array}{l}\text { Plant } \\
\text { combination }\end{array}$} & \multicolumn{7}{|c|}{ Number of plants per hectare (stems) } \\
\hline & & $\begin{array}{l}\text { Oil } \\
\text { Palm }\end{array}$ & $\begin{array}{l}\text { Jengkol } \\
(3 \times 3 \mathrm{~m})\end{array}$ & $\begin{array}{l}\text { Petai } \\
(3 \times 3)\end{array}$ & $\begin{array}{l}\text { Durian } \\
(5 \times 5 \mathrm{~m})\end{array}$ & $\begin{array}{l}\text { Sungkai } \\
(3 \times 3 \mathrm{~m})\end{array}$ & $\begin{array}{l}\text { Meranti } \\
(3 \times 3 \mathrm{~m})\end{array}$ & $\begin{array}{l}\text { Jelutong } \\
(3 \times 4 \mathrm{~m})\end{array}$ \\
\hline I & $\begin{array}{l}\text { Oil Palm- } \\
\text { monoculture }\end{array}$ & 140 & & & & & & \\
\hline II & $\begin{array}{l}\text { Oil Palm and } \\
\text { jengkol }\end{array}$ & 81 & 1,111 & & & & & \\
\hline III & $\begin{array}{l}\text { Oil Palm and } \\
\text { petai }\end{array}$ & 81 & & 1,111 & & & & \\
\hline IV & $\begin{array}{l}\text { Oil Palm and } \\
\text { durian }\end{array}$ & 81 & & & 400 & & & \\
\hline V & $\begin{array}{l}\text { Oil Palm and } \\
\text { sungkai }\end{array}$ & 81 & & & & 1,111 & & \\
\hline VI & $\begin{array}{l}\text { Oil Palm and } \\
\text { meranti }\end{array}$ & 81 & & & & & 1,111 & \\
\hline VII & $\begin{array}{l}\text { Oil Palm and } \\
\text { jelutong }\end{array}$ & 81 & & & & & & 833 \\
\hline
\end{tabular}


The terms and assumptions employed for the financial analysis follow those of oil palm agroforestry in Section 4.3 with the exception that the number of intercrop trees follows the optimal plant distance of each plant as indicated in Table 7. Table 8 shows a comparison of the financial feasibility with income and profit potential of each cropping pattern supported in the Harapan Rainforest.

Table 8. Comparison of the financial feasibility with income and profit potential of each cropping pattern supported in the Harapan Rainforest.

\begin{tabular}{|c|c|c|c|c|c|c|}
\hline \multirow[b]{2}{*}{ Pattern } & \multicolumn{6}{|c|}{ Financial Feasibility Criteria } \\
\hline & $\begin{array}{c}\text { Plant } \\
\text { combination }\end{array}$ & NPV (IDR (US\$)) & BCR & $\begin{array}{l}\text { IRR } \\
\text { (\%) }\end{array}$ & $\begin{array}{c}\text { Potential } \\
\text { Income (IDR } \\
\text { (US\$)/hectare } \\
\text { /month) }\end{array}$ & $\begin{array}{c}\text { Potential Profit } \\
\text { (IDR(US\$)/hectare } \\
\text { /month) }\end{array}$ \\
\hline 1 & $\begin{array}{l}\text { Oil Palm } \\
\text { monoculture }\end{array}$ & $\begin{array}{c}62,644,836 \\
(4,454.49)\end{array}$ & 1.39 & 20.77 & $\begin{array}{c}2,371,069 \\
(168.60)\end{array}$ & $986,874(70.17)$ \\
\hline II & $\begin{array}{l}\text { Oil Palm and } \\
\text { jengkol }\end{array}$ & $\begin{array}{c}209,996,929 \\
(14,932.30)\end{array}$ & 2.01 & 25.83 & $\begin{array}{c}6,022,434 \\
(428.24)\end{array}$ & $3,861,744(274.60)$ \\
\hline III & $\begin{array}{l}\text { Oil Palm with } \\
\text { petai }\end{array}$ & $\begin{array}{c}96,743,006 \\
(6,879.11)\end{array}$ & 1.56 & 22.94 & $\begin{array}{c}3,763,134 \\
(267.59)\end{array}$ & $2,161,076(153.67)$ \\
\hline IV & $\begin{array}{l}\text { Oil Palm and } \\
\text { durian }\end{array}$ & $\begin{array}{c}126,257,866 \\
(8,977.83)\end{array}$ & 1.65 & 23.5 & $\begin{array}{c}5,364,493 \\
(381.45)\end{array}$ & $3,119,061$ (221.79) \\
\hline V & $\begin{array}{l}\text { Oil Palm and } \\
\text { sungkai }\end{array}$ & $\begin{array}{c}51,634,692 \\
(3,671.59)\end{array}$ & 1.33 & 19.2 & $\begin{array}{c}3,008,877 \\
(213.95)\end{array}$ & $1,668,908(118.67)$ \\
\hline VI & $\begin{array}{l}\text { Oil Palm and } \\
\text { meranti }\end{array}$ & $\begin{array}{c}32,955,707 \\
(2,343.38)\end{array}$ & 1.21 & 17.94 & $\begin{array}{c}2,367,420 \\
(168.34)\end{array}$ & $1,035,996(73.67)$ \\
\hline VII & $\begin{array}{l}\text { Oil Palm with } \\
\text { jelutong }\end{array}$ & $\begin{array}{c}55,107,152 \\
(3,918.51)\end{array}$ & 1.34 & 19.73 & $\begin{array}{c}2,826,627 \\
(200.99)\end{array}$ & $1,342,595(95.47)$ \\
\hline
\end{tabular}

Table 8 shows that all oil palm agroforestry patterns are financially feasible. All financial criteria (NPV, BCR, and IRR) meet the threshold of financial feasibility where NPV $>0, B C R>1$, and IRR $>i$. This supports the previous study (Dhanny Yuniati, 2018), which reported that oil palm agroforestry generates a higher monthly income potential compared to monoculture-oil palm cultivation (Dhanny Yuniati, 2018).

To discuss the economic potential of oil palm agroforestry, it is very important to evaluate the household income and expenditure of the local community around Harapan Rainforest. Assuming the price of oil palm fresh fruit bunches (FFB) is IDR1,100/kg, a farmer will gain IDR1,060,000/ha/month from a monoculture oil palm plantation. According to the household's survey, the average monthly expenditure of a household is IDR4,100,000 (see Table 2), then the farmer has to manage at least 4 ha of oil palm monoculture to get a minimum income. Since people usually have just less than 1 ha of land, then people plant oil palm in the forests to meet the needs of more lands. The introduction of oil palm agroforestry will increase the productivity of the land. This only needs about 2-3 ha of land, or half of land with oil palm monoculture, to meet the household's needs. It means oil palm agroforestry will potentially reduce land encroachment in the Harapan Rainforest.

Considering the different ethnic groups of the local community, it is necessary to use several approaches to introduce the oil palm agroforestry in Harapan Rainforest. Migrant people who have better knowledge and skills to practice modern agriculture will be easier to adopt oil palm agroforestry. Different from migrant people, native groups of Malay and Batin Sembilan are usually still practicing traditional agriculture, some of them are even doing shifting agriculture. Therefore, providing technical assistance and demonstration plots, as well as making social and cultural approaches are required to give a better opportunity on oil palm agroforestry for the native groups. 


\subsection{Ecological impacts of oil palm agroforestry}

The conversion of forests to oil palm plantations causes disturbances to the habitat of certain fauna, such as mammals-including Sus scrofa, Macaca fascicularis, and Macaca nemestrina Trachypithecus obscurus, Trachypithecus cristatus, Viverra tangalunga, and Prionailurus bengalensis (Azhar et al., 2014)-soil macro-fauna, and birds (Ashton-Butt et al., 2018; Azhar et al., 2014; Teuscher et al., 2016). Thus, large-scale oil palm plantations that are managed using monoculture will potentially damage the landscape and biodiversity. The oil palm plantation companies usually eradicate understory vegetation to increase oil palm yields which decimates in-soil macro-fauna diversity (Ashton-Butt et al., 2018).

Interestingly, there are some impressive effects of enrichment planting affecting birds and invertebrate fauna a year after the establishment of the experimental agroforestry plot. Research confirms an increase in invertebrates present on enrichment planting experimental plots (Teuscher et al., 2016), with most of the insects found in the herb layer (Teuscher et al., 2016). The research also found an increase in bird diversity, probably caused by an overall increase in heterogeneity within the experimental plot (Teuscher et al., 2016). After the first year, some of the planted trees had already reached more than four meters in height (Teuscher et al., 2016) to provide nesting, roosting, and foraging habitats (Thiollay, 1995). The presence of birds and invertebrate fauna can be used as bio-indicators to monitor the improvement in habitat quality (Barnes et al., 2014; Ewers et al., 2015; Sekercioglu, 2006). The invertebrates perform many functions, including litter decomposition, predation, pollination, and herbivory, which are critical for the functioning of the ecosystem (Ewers et al., 2015). The initial positive effects on birds and invertebrates are key to the initiation of natural succession by other organisms that are essential for biodiversity enrichment into the future (Teuscher et al., 2016).

Finally, another interesting point is the impressively increasing oil palm yields, even though it was mitigated by the loss of oil palm yields at the plot scale during the initial experimental stage (Woittiez et al., 2017). The oil palm height as a proxy for the oil-palm age was the most important indicator of yields (Gérard et al., 2017). Therefore, the increased oil palm height (and consequently age) indicates higher oil-palm yields in the experimental plot.

\section{Concluding Remarks}

This research concludes that the establishment of oil palm agroforestry is promising in reconciling the conflict of interests between PT REKI and the local communities around the Harapan Rainforest. It indicates that oil palm agroforestry provides a higher financial benefit compared to oil palm-monoculture. A combination of oil palm and jengkol will produce the highest monthly profits compared to oil palm monoculture and other intercrops. A two-hectare agroforest with a combination of oil palm and jengkol will be able to sustain the average monthly expenditure needs of the local community around the Harapan Rainforest.

A relatively wide planting distance enables the maintenance of facilities and effective management activities. The determination of spacing affects costs and income from the applied land management patterns. Moreover, plant spacing also affects plant growth, contributing directly to the success of oil palm agroforestry.

Oil palm agroforestry offers positive ecological impacts, such as improving the flora diversity as the habitat of specific fauna. However, since this requires removing some oil palm trees, not all local communities around the Harapan Rainforest are willing to participate. The increased benefits from intercropping and oil palm yields in the initial stages of agroforestry may compensate for the reduction in yield from the removal of oil palm trees. These potential benefits should be thoroughly explained to the local communities for them to accept and implement oil palm agroforestry.

In conclusion, this study confirms additional benefits in the economic and ecological aspects of oil palm agroforestry compared to oil palm-monoculture. It recommends an optimal combination of crops in oil palm agroforestry. These results provide rational evidence supporting the expansion of oil palm agroforestry in land use planning. 
Author Contributions: Conceptualization DN, YH, MP; methodology DN, YH, MP; software TR; validation DN, $T R, R B, A S$; formal analysis TR, DN, YH, MP, RB; investigation TR; resources DN, TR, MP, AS; data curation TR.; writing-original draft preparation TR, DN; writing-review and editing DN, YH, MP, RB, AS; visualization TR.; supervision DN, YH, MP, RB; project administration TR, DN, AS; funding acquisition DN, AS. All authors have read and agreed to the published version of the manuscript.

Funding: This research was funded by the PMDSU-Ministry of Research and Technology-Research and the Innovation Agency of the Republic of Indonesia, following the 2020 Research Implementation Assignment Agreement, Number: 1/E1/KP.PTNBH/2020 and partly funded by ABS Fund of CRC 990-EFForTS (DFG), PTUPT and WCR Program Kemdikbud Ristek 2021.

Conflicts of Interest: The authors declare no conflict of interest. The funders had no role in the design of the study; in the collection, analyses, or interpretation of data; in the writing of the manuscript, or in the decision to publish the results.

Competing interests: The authors declare that this research has no competing interests.

Acknowledgments: We would like to express thanks to the CRC-990/EFForTS and PT REKI for all assistance during the field research. Our sincere thanks also go to all respondents and the local community in Bungku Village for their kind support and hospitality. We gratefully acknowledge the PMDSU scholarship 2018-2022, ABS Fund of CRC 990-EFForTS (DFG), PTUPT and WCR Grant Kemdikbud Ristek 2021 that provided funding for this study, and the Creative-Pioneering Researchers Program through Seoul National University for the English editing assistance.

\section{References}

Adalina, Y., Nurrochmat, D. R., Darusman, D., \& Sundawati, L. (2014). Harvesting of non-timber forest products by the local communities in Mount Halimun-Salak National Park, West Java, Indonesia. Jurnal Manajemen Hutan Tropika, 20(2), 103-111. http://dx.doi.org/10.7226/jmht.20.2.103

Allen, K., Corre, M. D., Tjoa, A., \& Veldkamp, E. (2015). Soil nitrogen-cycling responses to conversion of lowland forests to oil palm and rubber plantations in Sumatra, Indonesia. Plos One, 10(7), 121. https://doi.org/10.1371/journal.pone.0133325

Ashton-Butt, A., Aryawan, A. A. K., Hood, A. S. C., Naim, M., Purnomo, D., Suhardi, .. S Snaddon, J. L. (2018). Understory vegetation in oil palm plantations benefits soil biodiversity and decomposition rates. Frontiers in Forests and Global Change, 1(10). https://doi.org/10.3389/ffgc.2018.00010

Azhar, B., Lindenmayer, D., Wood, J., Fischer, J., Manning, A., McElhinny, C., \& Zakaria, M. (2014). Ecological impacts of oil palm agriculture on forest mammals in plantation estates and smallholdings. Biodiversity and Conservation, 23(5), 1-9. https://doi.org/10.1007/s10531-0140656-z

Barnes, A. D., Jochum, M., Mumme, S., Haneda, N. F., Farajallah, A., Widarto, T. H., \& Brose, U. (2014). Consequences of tropical land use for multitrophic biodiversity and ecosystem functioning. Nature communications, 5(1), 1-7. https://doi.org/10.1038/ncomms6351

[BPS-Jambi] Badan Pusat Statistika Jambi. (2020). Provinsi Jambi dalam Angka 2019. BPS Provinsi Jambi

[BPS] Badan Pusat Statistik. (2020). Statistik Kelapa Sawit Indomesia 2019 - Indonesian Oil Palm Statistics 2019. Badan Pusat Statistik/BPS-Statistics Indonesia

Cole, R. J., Holl, K. D., \& Zahawi, R. A. (2010). Seed rain under tree islands planted to restore degraded lands in a tropical agricultural landscape. Ecological Applications, 20(5), 1255-1269. https://doi.org/10.1890/09-0714.1

Cooper, H. V., Vane, C. H., Evers, S., Paul Apline, Girkina, N. T., \& Sjögersten, S. (2019). From peat swamp forest to oil palm plantations: The stability of tropical peatland carbon. Geoderma, 342, 109-117. https://doi.org/10.1016/j.geoderma.2019.02.021 
Drescher, J., Rembold, K., Allen, K., Beckschäfer, P., Buchori, D., Clough, Y., . . . Scheu, S. (2016). Ecological and socio-economic functions across tropical land use systems after rainforest conversion. Philosophical Transactions of the Royal Society B: Biological Sciences, 371, 1-8. https://doi.org/10.1098/rstb.2015.0275

Erbaugh, J. T., \& Nurrochmat, D. R. (2019). Paradigm shift and business as usual through policy layering: Forest-related policy change in Indonesia (1999-2016). Land Use Policy, 86, 136-146. https://doi.org/10.1016/j.landusepol.2019.04.021

Ewers, R. M., Boyle, M. J., Gleave, R. A., Plowman, N. S., Benedick, S., Bernard, H., ... \& Turner, E. C. (2015). Logging cuts the functional importance of invertebrates in tropical rainforest. Nature communications, 6(1), 1-7. https://doi.org/10.1038/ncomms 7836

Foster, W. A., Snaddon, J. L., Turner, E. C., Fayle, T. M., Cockerill, T. D., Ellwood, M. D. F., . . Yusah, K. M. (2011). Establishing the evidence base for maintaining biodiversity and ecosystem function in the oil palm landscapes of South East Asia. Philosophical Transactions of The Royal Society Biological Sciences, 366, 3277-3291. https://doi.org/10.1098/rstb.2011.0041

Gellert, P. K. (2015). Palm Oil Expansion in Indonesia: Land Grabbing as Accumulation by Dispossession. In States and Citizens: Accommodation, Facilitation and Resistance to Globalization. Emerald Group Publishing Limited.

Gérard, A., Wollni, M., Hölscher, D., Irawan, B., Sundawati, L., Teuscher, M., \& Kreft, H. (2017). Oilpalm yields in diversified plantations: Initial results from a biodiversity enrichment experiment in Sumatra, Indonesia. Agriculture, Ecosystems and Environment, 240, 253-260. https://doi.org/10.1016/j.agee.2017.02.026

Gittinger, Price, J., \& Hans, A. A. (1993). Analisis Ekonomi Proyek-Proyek Pertanian. PT. Rineka Cipta. Hadi, A. Q., \& Napitupulu, R. M. (2011). 10 Tanaman Investasi Pendulang Rupiah. Penebar Swadaya.

Harbi, J., Erbaugh, J. T., Sidiq, M., Haasler, B., \& Nurrochmat, D. R. (2018). Making a bridge between livelihoods and forest conservation: Lessons from non timber forest products' utilization in South Sumatera, Indonesia. Forest Policy and Economics, 94, 1-10. https://doi.org/10.1016/j.forpol.2018.05.011

Immerzeel, D. J., Verweij, P. A., van der Hilst, F., \& Faaij, A. P. C. (2014). Biodiversity impacts of bioenergy crop production: a state-of-the-art review. GCB Bioenergy, 6(3), 183-209. https://doi.org/10.1111/gcbb.12067

Kadariah, Karline, L., \& Gray, C. (1999). Pengantar Evaluasi Proyek. Lembaga Penerbit Fakultas Ekonomi UI.

Kehati. (2019). Hutan Kita Bersawit: Gagasan Penyelesaian untuk Perkebunan Kelapa Sawit dalam Kawasan Hutan. Yayasan KEHATI.

Khasanah, N., van Noordwijk, M., Slingerland, M., Sofiyudin, M., Stomph, D., Migeon, A. F., \& Hairiah, K. (2020). Oil Palm Agroforestry Can Achieve Economic and Environmental Gains as Indicated by Multifunctional Land Equivalent Ratios. Frontiers in Sustainable Food Systems, 3(122). https://doi.org/10.3389/fsufs.2019.00122

Kiswanto, Hadipurwanta, J., \& Wijayanto, B. (2008). Teknologi budidaya Kelapa Sawit. Balai Besar pengkajian dan Pengembangan Teknologi Pertanian.

Koh, L. P., Levang, P., \& Ghazoul, J. (2009). Designer landscapes for sustainable biofuels. Trends in Ecology \& Evolution, 24(8), 431-438. https://doi.org/10.1016/j.tree.2009.03.012

Koh, L. P., \& Wilcove, D. S. (2008). Is oil palm agriculture really destroying tropical biodiversity? Conservation Letters, 1, 60-64. https://doi.org/10.1111/j.1755-263X.2008.00011.x

Koh, L. P., \& Wilcove, D. S. (2009). Oil palm: disinformation enables deforestation. Trends in Ecology \& Evolution, 24(2), 67-80. https://doi.org/10.1016/j.tree.2008.09.006

Lambin, E. F., \& Meyfroidt, P. (2011). Global land use change, economic globalization, and the looming land scarcity. Proceedings of the National Academy of Sciences, 108(9), 3465-3472. https://doi.org/10.1073/pnas.1100480108

Lubis, R. E., \& Widanarko, A. (2012). Buku Pintar Kelapa Sawit. AgroMedia Pustaka.

[MoA] Ministry of Agriculture. (2019). Statistik Perkebunan Indonesia 2018-2020-Tree Crop Estate 
Statistics Of Indonesia 2018-2020. Ditjenbun, Ministry of Agriculture, Republic of Indonesia

[MoEF] Ministry of Environment and Forestry. (2018). Hutan Harapan di Jambi Kian Tertekan. Accessed at 11/02/2021. Retrieved from http://perpustakaan.menlhk.go.id/pustaka/home/index.php?page=detail_news\&newsid=557

[MoEF] Ministry of Environment and Forestry. (2019). Rekalkulasi Penutupan Lahan Indonesia Tahun 2018. Ministry of Environment and Forestry, Republic of Indonesia

[MoEF] Ministry of Environment and Forestry. (2020). Regulation of the Director General of Sustainable Production Forest Management Number: P.1/PHPL/SET/KUM.1/5/2020 concerning Procedures for Application, Assignment and Implementation of the Multi-business Forestry Model for Business License Holders for the Utilization of Timber Forest Products in Production Forests. Directorate General of Sustainable Production Forest Management, Ministry of Environment and Forestry

Muryunika, R. (2015). Strategi Pengelolaan dan Pengembangan Agroforestri Berbasis Kelapa Sawit di Jambi. (Master Thesis). Sekolah Pascasarjana Institut Pertanian Bogor.

Nair, P.K., \& Garrity, D. (2012). Agroforestry - The Future of Global Land Use. Springer.

Nair, P. K. (1993). An Introduction to Agroforestry. Kluwer Academic Publisher.

Nurrochmat, D. R. (2017). Strategi Kebijakan Pembangunan Kehutanan dan Lingkungan. IPB Press.

Nurrochmat, D. R., Boer, R., Ardiansyah, M., Immanuel, G., \& Purwawangsa, H. (2020). Policy forum: Reconciling palm oil targets and reduced deforestation: Landswap and agrarian reform in Indonesia. Forest Policy and Economics, 119, 102291. https://doi.org/10.1016/j.forpol.2020.102291

Nurrochmat, D. R., Nugroho, I. A., Hardjanto, Purwadianto, A., Maryudi, A., \& Erbaugh, J. T. (2017). Shifting contestation into cooperation: Strategy to incorporate different interest of actors in medicinal plants in Meru Betiri National Park, Indonesia. Forest Policy and Economics, 83, 162168. https://doi.org/10.1016/j.forpol.2017.08.005

Nurrochmat, D.R., Pribadi, R., Siregar, H., Justianto. A., \& Park, M.S. (2021). Transformation of AgroForest Management Policy under the Dynamic Circumstances of a Two-Decade Regional Autonomy in Indonesia. Forests, 12(4), 1-17. https://doi.org/10.3390/f12040419

Phalan, B., Fitzherbert, E. B., Rafflegeau, S., J.Struebig, M., \& Verwilghen, A. (2009). Conservation in oil-palm landscapes. Conservation Biology, 23(2), 244-245. https://doi.org/10.1111/j.15231739.2008.01153.x

Phimmavong, S., Maraseni, T., Keenan, R., \& Cockfield, G. (2019). Financial returns from collaborative investment models of Eucalyptus agroforestry plantations in Lao PDR. Land Use Policy, 87, 1-11. https://doi.org/10.1016/j.landusepol.2019.104060

Pitojo, S. (1992). Jengkol, Budidaya dan Pemanfaatannya. Kanisius.

REKI, P. (2008). Proposal Teknis Permohonan Izin Usaha Pemanfaatan Hasil Hutan Kayu Restorasi Ekosistem pada Kawasan Hutan Produksi Kabupaten Batang Hari dan Kabupaten Sarolangun Provinsi Jambi. [Press release]

REKI, P. (2009). Rencana Kerja Usaha Pemanfaatan Hasil Hutan Kayu Restorasi Ekosistem dalam Hutan Alam pada Hutan Produksi Periode Tahun 2011-2020 [Press release].

Sahide, M.A.K., Burns, S., Wibowo, A., Nurrochmat, D.R., \& Giessen, L. (2015a). Towards state hegemony over agricultural certification: from voluntary private to mandatory state regimes on palm oil in Indonesia. Jurnal Manajemen Hutan Tropika, 21(3), 162-171. http://dx.doi.org/10.7226/jtfm.21.3.162

Sahide, M.A.K, Nurrochmat, D.R., \& Giessen, L. (2015b). The regime complex for tropical rainforest transformation: Analysing the relevance of multiple global and regional land use regimes in Indonesia. Land Use Policy, 47, 408-425. http://dx.doi.org/10.1016/j.landusepol.2015.04.030

Sekercioglu, C. H. (2006). Increasing awareness of avian ecological function. Trends in Ecology \& Evolution, 21(8), 464-471. https://doi.org/10.1016/j.tree.2006.05.007

Sequiño, A. C., \& Avenido, J. (2015). The world's leader in the palm oil industry: Indonesia. 
International Journal of Ecology and Conservation, 13(1), 152-164. http://dx.doi.org/10.7718/ijec.v13i1.1074

Setiawan, A., Mardhiansyah, M., \& Sribudiani, E. (2015). Respon pertumbuhan semai meranti tembaga (Shorea leprosula Miq.) pada medium campuran topsoil dan kompos dengan berbagai tingkat naungan. JOM Faperta, 2(2), 5-6.

Sheriffdeen, M., Nurrochmat, D.R., Perdinan, \& Di Gregorio, M. (2020). Indicators to Evaluate the Institutional Effectiveness of National Climate Financing Mechanisms. Forest and Society, 4(2): 358-378. http://dx.doi.org/10.24259/fs.v4i2.10309

Sobir. (2009). Buku Pintar Budi Daya Tanaman Buah Unggul Indonesia. AgroMedia Pustaka.

Sobir, \& Napitupulu, R. M. (2010). Bertanam Durian Unggul. Penebar Swadaya.

Sufriadi. (2015). Analisis Produksi dan Produktivitas Perkebunan Kelapa Sawit Rakyat di Kabupaten Aceh Selatan. (Master Thesis). Universitas Sumatera Utara.

Sumarga, E., \& Hein, L. (2016). Benefits and costs of oil palm expansion in Central Kalimantan, Indonesia, under different policy scenarios. Regional Environmental Change, 16, 1011-1021. https://doi.org/10.1007/s10113-015-0815-0

Sunanto, H. (1999). Seri Budidaya Petai. Kanisius.

Susilo, J. (2012). Budidaya Petai Prospek Pasar Terbuka Lebar. Pustaka Baru Press.

Sutojo, S. (2000). Studi Kelayakan Proyek, Teori dan Praktek. Gramedia.

Syuroh, M. (2011). Sosial dan kebudayaan kelompok minoritas di Indonesia (Studi Kasus Kelompok "Batin Sembilan" di Provinsi Jambi). Masyarakat, Kebudayaan dan Politik, 24(1), 17-23.

Tata, H. L., Bastoni, Sofiyuddin, M., Mulyoutami, E., Perdana, A., \& Janudianto. (2015). Jelutung Rawa Teknik Budidaya dan Prospek Ekonominya. World Agroforestry Centre (ICRAF).

Teuscher, M., Gérard, A., Brose, U., Buchori, D., Clough, Y., Ehbrecht, M., . . . Kreft, H. (2016). Experimental Biodiversity Enrichment in Oil-Palm-Dominated Landscapes in Indonesia. Frontiers in plant science, 7, 1538-1538. https://doi.org/10.3389/fpls.2016.01538

Thiollay, J. M. (1995). The role of traditional agroforests in the conservation of rain forest bird diversity in Sumatra. Conservation Biology, 9(2), 335-353. https://doi.org/10.1046/j.15231739.1995.9020335.x

Vijay, V., Pimm, S. L., Jenkins, C. N., \& Smith, S. J. (2016). The impacts of oil palm on recent deforestation and biodiversity loss. PLoS One, 11(7), 1-19. https://doi.org/10.1371/journal.pone.0159668

Wahyudi. (2016). Analisis pertumbuhan dan finansial tanaman sungkai (Peronema canescens) di Kapuas, Kalimantan Tengah. Jurnal Hutan Tropika, 11(2), 56-64. https://doi.org/10.36873/jht.v11i2.47

Wahyudi, Damiri, M., Christopheros, \& Pahawang. (2018). Kualitas kayu sungkai (Peronema canescens) dan sengon (Paraserianthes falcataria) pada hutan rakyat di Kabupaten Tabalong Kalimantan Selatan. Jurnal Hutan Tropika, 13(1), 10-18. https://doi.org/10.36873/jht.v13i1.285

Wanderi, Qurniati, R., \& Kaskoyo, H. (2019). Kontribusi tanaman agroforestri terhadap pendapatan dan kesejahteraan petani. Jurnal Sylva Lestari, 7(1), 118-127. http://dx.doi.org/10.23960/jsl17118-127

Widayati, A., Johana, F., Zulkarnain, M., \& Mulyoutami, E. (2012). Perubahan Penggunaan Lahan, Faktor Pemicu dan Pengaruhnya terhadap Emisi CO2 di Tanjung Jabung Barat, Jambi. World Agroforestry Center - ICRAF SEA Regional Office.

Wijayanti, R. T., \& Mudakir, B. (2013). Analisis keuntungan dan skala usaha perkebunan kelapa sawit gerbang serasan. Diponegoro Journal of Economics, 2(1), 1-7.

Woittiez, L. S., Wijk, M. T. v., Slingerland, M., Noordwijka, M., \& E.Gillera, K. (2017). Yield gaps in oil palm: A quantitative review of contributing factors. European Journal of Agronomy, 83, 57-77. https://doi.org/10.1016/j.eja.2016.11.002

Yovi, E. Y., \& Nurrochmat, D. R. (2018). An occupational ergonomics in the Indonesian state mandatory sustainable forest management instrument: A review. Forest Policy and Economics, 91, 27-35. https://doi.org/10.1016/j.forpol.2017.11.007 
Yuniati, D. (2018). Analisis Kelayakan Restorasi Hutan Lindung Gambut Berbasis Masyarakat. (Master Thesis). Sekolah Pascasarjana Institut Pertanian Bogor.

Yuniati, D., Nurrochmat, D. R., Anwar, S., \& Darwo. (2018). Penetapan pola rehabilitasi pemulihan fungsi ekosistem hutan lindung gambut Sungai Bram Itam di Kabupaten Tanjung Jabung Barat, Provinsi Jambi. Jurnal Penelitian Hutan Tanaman, 15(2), 67-85. https://doi.org/10.20886/jpht.2018.15.2.67-85 